\title{
2. THE D'ENTRECASTEAUX ZONE-NEW HEBRIDES ISLAND ARC COLLISION ZONE: AN OVERVIEW 1
}

\author{
J.-Y. Collot ${ }^{2}$ and M. A. Fisher ${ }^{3}$
}

\begin{abstract}
The d'Entrecasteaux Zone, encompassing the North d'Entrecasteaux Ridge and the Bougainville Guyot, collide with the central New Hebrides Island Arc. The d'Entrecasteaux Zone trends slightly oblique to the $10-\mathrm{cm} / \mathrm{yr}$ relative direction of plate motion so that the ridge and the guyot scrape slowly $(2.5 \mathrm{~cm} / \mathrm{yr})$ north, parallel to the trench. The North d'Entrecasteaux Ridge consists of Paleogene mid-ocean ridge basalt basement and Pliocene to Pleistocene sediment. The Bougainville Guyot is an andesitic, middle Eocene volcano capped with upper Oligocene to lower Miocene and Miocene to Pliocene lagoonal limestones.

Geophysical and geologic data collected prior to Leg 134 indicate that the two collision zones differ in morphology and structure. The North d'Entrecasteaux Ridge extends, with a gentle dip, for at least $15 \mathrm{~km}$ eastward beneath the arc slope and has produced a broad $(20-30 \mathrm{~km}$ ), strongly uplifted area (possibly by $1500-2500 \mathrm{~m})$ that culminates at the Wousi Bank. This tectonic pattern is further complicated by the sweeping of the ridge along the trench, which has produced a lobate structure formed by strike-slip and thrust faults as well as massive slumps north of the ridge. South of the ridge, the sweeping has formed large normal faults and slump scars that suggest collapse of arc-slope rocks left in the wake of the ridge. In the Bougainville collision zone, the unbroken cap of the guyot extends for only $1 \mathrm{~km}$ eastward beneath the arc slope. In contrast with the arc slope landward of the North d'Entrecasteaux Ridge, the arc slope east of the guyot has been deeply indented and considerably shortened along east-dipping thrust faults. The only equivalent to the Wousi Bank that has developed east of the guyot is a narrow compressive antiform $800 \mathrm{~m}$ in height.

The collision zones between the North d'Entrecasteaux Ridge and Bougainville Guyot show some similarities. Seismic reflection data suggest that in both zones material from the downgoing plate may accrete locally to the arc slope. Moreover, the arc slope in both collision zones is affected by large mass wasting and strong tectonic erosion. Geophysical data suggest that slump material may be as thick as 2-3 km along the arc slope. Tectonic erosion reaches a maximum when arc-slope rocks collapse in the wake of the North d'Entrecasteaux Ridge and after a seamount disappears in the subduction zone as in the case of the Malakula reentrant south of the Bougainville Guyot. This deep morphological reentrant is interpreted as a scar of a past collision and subduction of a seamount.

Geologic data collected during Nautile dives along the arc slope east of the d'Entrecasteaux Zone indicate that the superficial lithology of the arc slope consists of Pliocene to Pleistocene volcaniclastic rocks and sediments derived from the island arc. However, massive lavas and accreted rocks were also found locally along the arc slope. The presence of fractured andesite exposed along the south flank of the Wousi Bank suggests that the North d'Entrecasteaux Ridge collision deformed the island-arc basement. At the toe of the arc slope, against the ridge's north flank, sheared upper Oligocene to lower Miocene nannofossil ooze and chalk are interpreted as rocks accreted from the downgoing plate. Landward of the Bougainville Guyot, a 500 -m-thick wedge, including imbricated upper Oligocene to lower Miocene reefal limestones with upper Eocene reefal debris and middle Eocene pelagic sediments, could have formed by tectonic accretion of guyot material.
\end{abstract}

\section{INTRODUCTION}

Subduction of oceanic crust along modern convergent margins is either associated with tectonic erosion or tectonic accretion of sediment from the downgoing plate to the overriding plate. These processes are further complicated when large topographic irregularities of the seafloor, such as ridges or seamounts, collide with the inner wall of the trench (Fryer and Smoot, 1985; Collot et al., 1985; Fisher, 1986; Kobayashi et al., 1987; Lallemand and Le Pichon, 1987; Ballance et al., 1989; von Huene and Lallemand, 1990; Pelletier and Dupont, 1990). The influence of the collision on the structure of the active margin depends on various parameters, including the angle of convergence, the stress regime of the subduction zone, and the shape and lithology of both the colliding feature

\footnotetext{
${ }^{1}$ Collot, J.-Y., Greene, H. G., Stokking, L. B., et al., 1992. Proc. ODP, Init. Repts., 134: College Station, TX (Ocean Drilling Program).

${ }^{2}$ Laboratoire de Geodynamique, ORSTOM, B.P. 48, 06230 Villefranchesur-Mer, France.

${ }^{3}$ U.S. Geological Survey, 345 Middlefield Rd., Menlo Park, CA 94025 , U.S.A.
}

and the margin. The Bougainville Guyot and the North d'Entrecasteaux Ridge (NDR), parts of the d'Entrecasteaux Zone (DEZ), collide with the New Hebrides Island Arc within $80 \mathrm{~km}$ of each other (Fig. 1). These two collisions have resulted in contrasting morphologic and structural patterns in the arc slope.

In this paper we present an overview of the morphology, tectonics, and lithology of these two collision zones as deduced from Seabeam bathymetric data, multichannel seismic reflection profiles, dredging, and dive observations collected during American and French cruises. Seabeam bathymetric data were collected in 1985 during the SEAPSO cruise aboard the $J$. Charcot and multichannel seismic reflection profiles were acquired aboard the $S . P$. Lee and the J. Charcot, respectively, during the Tripartite cruises in 1982 and 1984 and during the MULTIPSO cruise in 1987. Dredge samples were collected during the SEAPSO cruise whereas in-situ observations and sampling were performed in 1989 using the deep-sea submersible Nautile (Fig. 2) during the SUBPSO cruise of the Nadir.

The New Hebrides Island Arc extends in a north-south direction over $1700 \mathrm{~km}$ and separates the Australia-India plate 


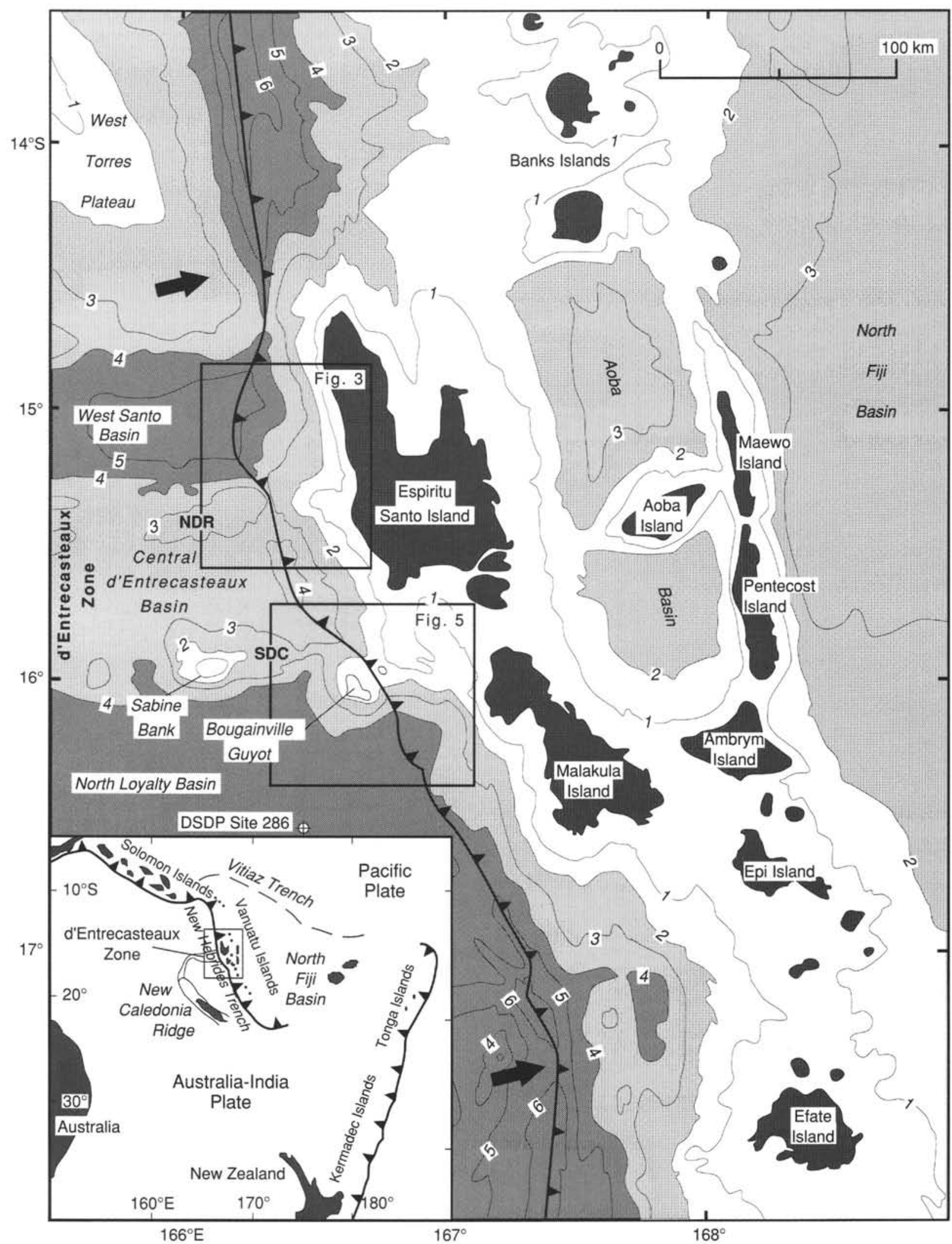

Figure 1. Map of the central New Hebrides Island Arc showing the location of the study area. NDR = North d'Entrecasteaux Ridge, SDC $=$ South d'Entrecasteaux Chain. Bathymetry in kilometers. 


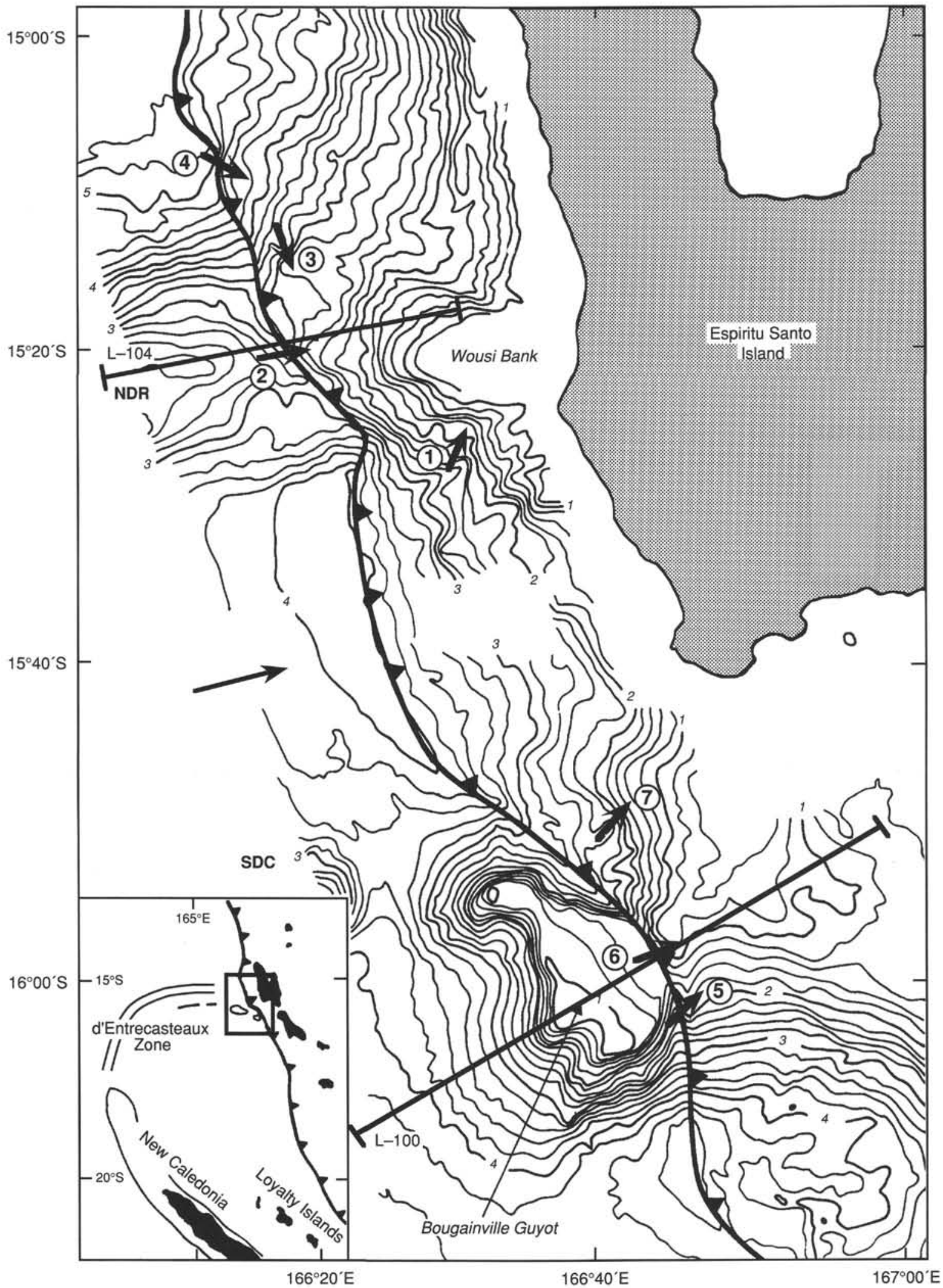

Figure 2. Generalized Seabeam map of the collision zone between the d'Entrecasteaux Zone and the New Hebrides Island Arc (Daniel et al., 1986) showing the location of two selected multichannel seismic reflection lines, L-100 and L-104. Circled numbers 1 to 7 are the location of the Nautile dives. NDR = North d'Entrecasteaux Ridge; SDC $=$ South d'Entrecasteaux Chain. Bathymetry in kilometers; contour interval is $200 \mathrm{~m}$. 
on the west from the North Fiji Basin and Pacific plate to the east (Fig. 1). The Australia-India plate has an absolute motion of $5 \mathrm{~cm} / \mathrm{yr}$ toward the north (Minster and Jordan, 1978), whereas the North Fiji Basin has been expanding in an east-west direction since $3 \mathrm{Ma}$ (Chase, 1971; Auzende et al., 1988), resulting in relative plate motion at the New Hebrides Trench of $\mathrm{N} 76 \pm 11^{\circ} \mathrm{E}, 9-10 \mathrm{~cm} / \mathrm{yr}$ (Isacks et al., 1981; Louat and Pelletier, 1989). The DEZ that is carried by the AustraliaIndia plate trends east-west, slightly oblique $\left(14^{\circ}\right)$ to the direction of relative plate convergence, so that during its subduction, the DEZ creeps slowly northward parallel to the trench at an average rate of $2.5 \mathrm{~cm} / \mathrm{yr}$. This oblique collision requires a continual structural adjustment of the arc slope that results in strata disruption, tectonic erosion of the arc-slope rocks, and possibly tectonic accretion.

In front of the DEZ, the central New Hebrides Island Arc includes three north-trending belts of islands with island arc rock foundations (see "Introduction" chapter, this volume). The Eastern Belt includes Maewo and Pentecost islands which consist of uppermost lower Miocene to lower Pliocene volcanic and volcaniclastic rocks capped with reef-derived carbonate and reefal limestone terraces uplifted during the earliest late Pliocene-Pleistocene (Macfarlane et al., 1988). The Central Belt includes Ambrym, Aoba, and the Banks islands, which represent the presently active island-arc volcanic line. The Western Belt that includes Espiritu Santo and Malakula islands, formed as a volcanic arc during the late Oligocene (?) to early Miocene (Mitchell and Warden, 1971; Carney and Macfarlane, 1982; Macfarlane et al., 1988) and was uplifted and eroded between the terminal middle Miocene and the latest Miocene. By the end of the Miocene a marine transgression deposited hemipelagic and pelagic sediments unconformably over the eroded basement. During the Pliocene the Western Belt rose and was covered with coral reefs (Mallick and Greenbaum, 1977, Carney and Macfarlane, 1982). The emergence of the Western Belt during the late Pliocene-Pleistocene is believed to correlate with the onset of the DEZ collision. The uplift rate of the western Espiritu Santo and northern Malakula islands reached 5-6 mm/yr during the Holocene (Jouannic et al., 1980; Taylor et al., 1980, 1987) (see Taylor, this volume).

In the following section, we present a synthesis of our knowledge of the d'Entrecasteaux Zone and related oceanic basins. Next we summarize the morphology, structure and lithostratigraphy of the NDR and Bougainville collision zones separately. Finally, we discuss the differences and similarities between the two collision zones.

\section{THE D'ENTRECASTEAUX ZONE AND SURROUNDING OCEAN BASINS}

The d'Entrecasteaux Zone is a submarine mountain chain that extends from the northern New Caledonia Ridge to the New Hebrides Trench and separates the North Loyalty Basin on its south side from the West Santo Basin (Fig. 1) to the north. Magnetic anomalies (Weissel et al., 1982) and drilling at Deep Sea Drilling Project (DSDP) Site 286 (Shipboard Scientific Party, 1975) suggest that the North Loyalty Basin was an active marginal basin expanding north-south or northeastsouthwest during the late Paleocene to the late Eocene. The age of the West Santo Basin is unknown. However, seismic refraction velocities (Pontoise and Tiffin, 1986), gravity anomalies (Collot and Fisher, 1988), basement morphology, and seismic reflection characteristics (Burne et al., 1988) suggest that the crusts of the North Loyalty and the West Santo basins either have different oceanic origins or have undergone deformation within different stress regimes. The crust of the North Loyalty Basin lies at a depth of $4500-5000 \mathrm{~m}$, is 10 to $12 \mathrm{~km}$ thick, and exhibits a 0 to $+30 \mathrm{mGal}$ gravity anomaly. The basement of the North Loyalty Basin is highly irregular and is covered by faulted sediments. The West Santo Basin lies at a depth of $5400 \mathrm{~m}$; the basin rocks cause an east-west-trending gravity low of $-180 \mathrm{mGal}$. The crust of this basin, which is about $13 \mathrm{~km}$ thick, has a smooth basement surface that deepens southward toward the NDR and is covered by a poorly deformed sedimentary wedge. The West Santo Basin has been interpreted as a former trench that formed at the site of an earlier south-directed subduction zone (Burne et al., 1988).

The DEZ consists of morphologically distinct western and eastern parts. Close to New Caledonia, the western DEZ encompasses an arcuate elongated graben that is flanked by subparallel horsts (Maillet et al., 1983), whereas the eastern DEZ widens to the east and bifurcates into the NDR and the South d'Entrecasteaux Chain (SDC) of seamounts (Daniel et al., 1977; Collot et al., 1985). The NDR is a relatively continuous east-west-trending morphologic high and the SDC consists of a series of seamounts and guyots-for example, Sabine Bank and the Bougainville Guyot (Daniel et al., 1986) (Fig. 1).

Near the New Hebrides Island Arc, the NDR is $2-4 \mathrm{~km}$ high, $40 \mathrm{~km}$ wide, and is topped by an east-west-trending crest that becomes flanked by flat shoulders at the contact with the tectonic front (Fig. 3). Here the ridge is characterized by an east-trending magnetic low that continues arcward, suggesting that the ridge extends beneath the arc slope (Collot and Fisher, 1991). This extension is clearly imaged by strong seismic reflection events at the top of the subducted ridge that can be traced beneath the arc slope for about $15 \mathrm{~km}$ (Fig. 4; Fisher et al., 1986). In contrast with the NDR, the Bougainville Guyot, which fills the New Hebrides Trench, is subcircular (about $50 \mathrm{~km}$ in base diameter) and has a high drag shape (Fig. 5). The slope of flanks of the guyot changes near $2000 \mathrm{~m}$ from a gentle $\left(4^{\circ}-6^{\circ}\right)$ lower slope to a steep $\left(25^{\circ}-30^{\circ}\right)$ upper slope. The guyot stands about $3 \mathrm{~km}$ above the surrounding oceanic plain and is topped by a sharp-edged flat platform (Daniel et al., 1986) that dips $4^{\circ}$ arcward, parallel to the flexured downgoing oceanic plate (Dubois et al., 1988).

The geology of the western horsts and the NDR differs from that of the Bougainville Guyot. Paleogene mid-ocean ridge basalt (MORB) was dredged from along the horsts and the NDR (Maillet et al., 1983) and seismic reflection data suggest that the NDR is covered by stratified sediments that return discontinuous reflections (Fig. 4; Fisher et al., 1991). These sediments include upper Pliocene and upper Pleistocene clay with Oligocene and Miocene displaced pelagic microfossils (Collot et al., unpubl. data). ${ }^{4}$ In contrast, the Bougainville Guyot is encircled by a highly reflective sedimentary apron that thickens downflank (Fig. 6) and becomes chaotic along its southern flank (Fisher et al., in press). Samples dredged from the south flank included island arc basalts, andesite, and uppermost middle Eocene to middle Oligocene volcanic breccia and conglomerate (Collot et al., in press). Late Pleistocene to Holocene silty clay with coral packstone and reefal debris dated from the late Oligocene to early Miocene were also recovered from this flank (Montaggioni et al., in press). The summit platform of the guyot consists of about $700 \mathrm{~m}$ of strongly reflective and well-bedded sediments that are affected by minor normal faults. Elongated

\footnotetext{
${ }^{4}$ Collot, J.-Y., Lallemand, S., Pelletier, B., Eissen, J.-P., Glaçon, G., Fisher, M. A., Greene, H. G., Boulin, J., Daniel, J., and Monzier, M. Geology of the d'Entrecasteaux-New Hebrides island arc collision zone: results from a deep-sea submersible survey (submitted to Tectonophysics).
} 


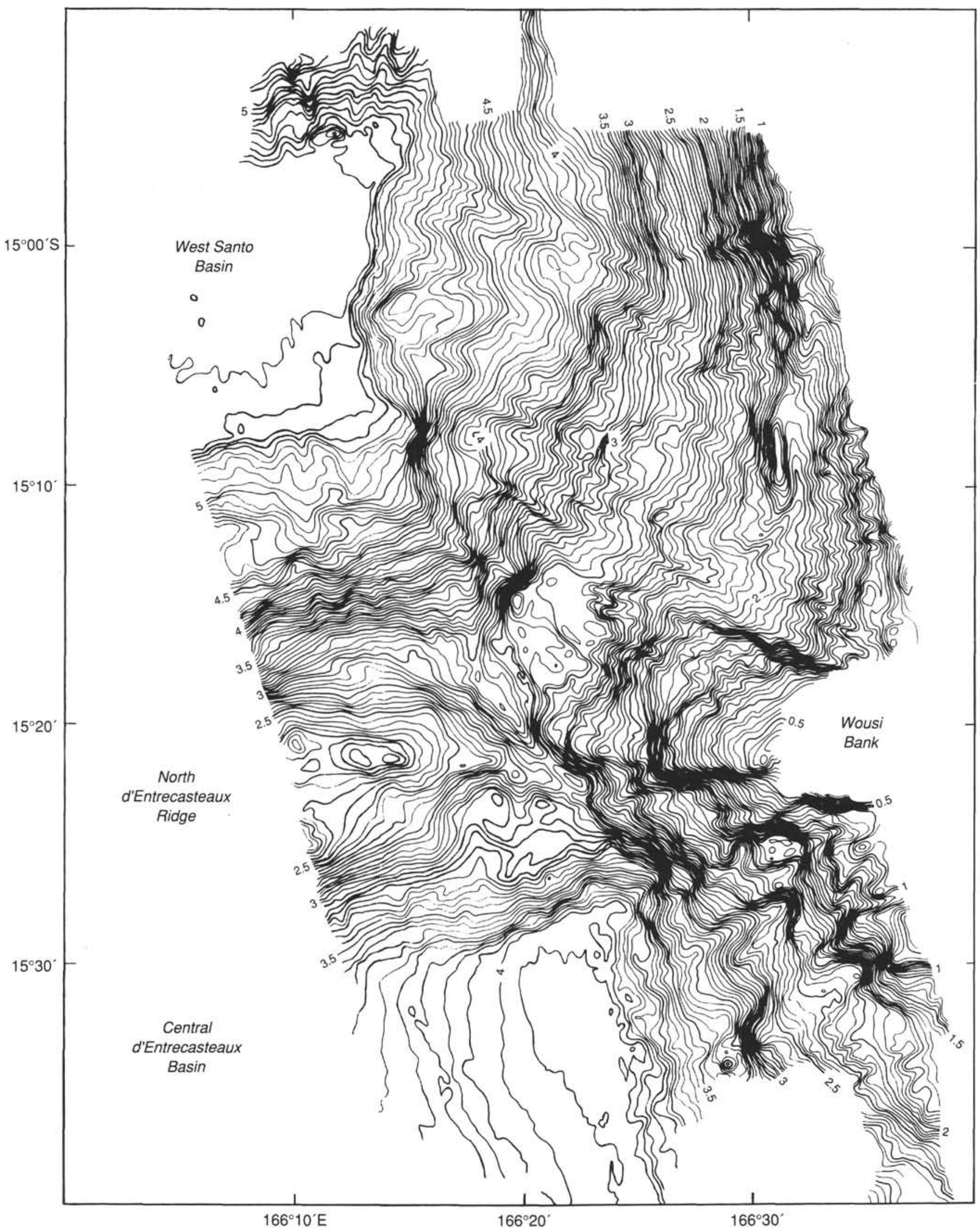

Figure 3. Seabeam bathymetric map of the collision zone between the North d'Entrecasteaux Ridge and the New Hebrides Island Arc. Bathymetry in kilometers; contour interval is $50 \mathrm{~m}$. The area covered is shown in Figure 1. 


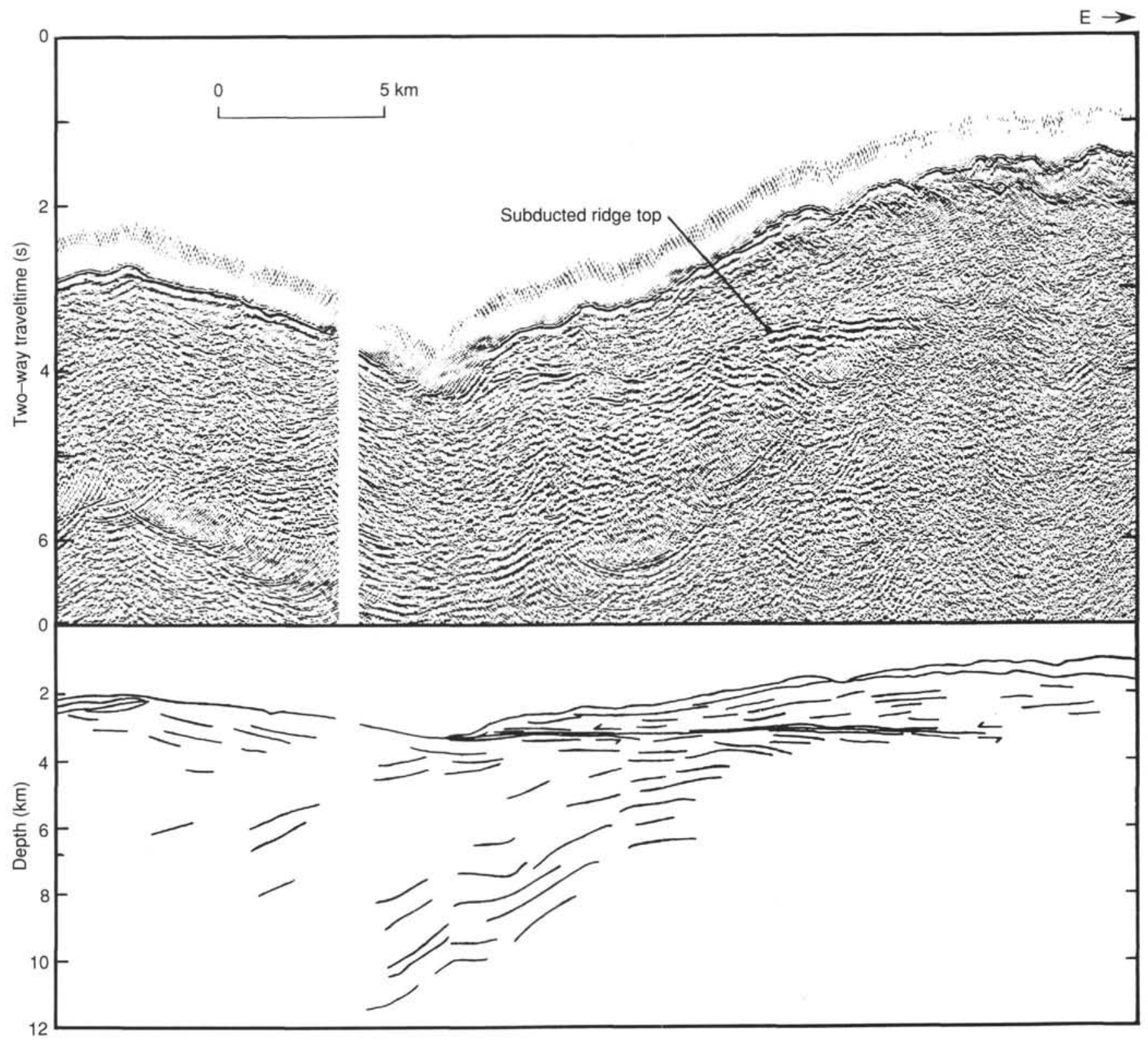

Figure 4. Migrated multichannel seismic reflection section (USGS line 104) across the North d'Entrecasteaux Ridge collision zone.

morphologic highs along the periphery of the platform together with dive observations suggest that this platform is a drowned atoll. Samples recovered from the platform include lagoonal deposits and coral limestones that developed during the late Oligocene to early Miocene and the Miocene to Pliocene. Montaggioni et al. (in press) present evidence for meteoric diagenesis of the limestones that indicate that the guyot probably emerged during the middle and late Miocene.

Several interpretations have been proposed for the plate tectonic setting of the DEZ. Initially called the d'Entrecasteaux Fracture Zone by Mallick (1973) and Luyendyk et al. (1974), the DEZ was later interpreted by Daniel et al. (1977) and Maillet et al. (1983) as the northern termination of the Eocene subduction/obduction zone that is now exposed on New Caledonia. Maillet et al. (1983) proposed that the present horst-and-graben morphology of the DEZ resulted from crustal extension in the middle Miocene. However, during the Eocene, while the North Loyalty Basin was active, the eastern DEZ may have been the site of a south-dipping subduction zone (Burne et al., 1988; Collot and Fisher, 1988). The trench-like morphology of the basement of the West Santo Basin, the island-arc affinities of rocks dredged from the Bougainville Guyot, and the middle Eocene andesitic conglomerate recovered at both the guyot and DSDP Site 286 support this interpretation.

\section{THE FOREARC SLOPE IN THE COLLISION ZONE}

The impingement of the DEZ against the arc has greatly altered the morphology and structure of the forearc slope. In response to the collision, the mountainous islands of Espiritu Santo and Malakula have risen east of the collision zone and the distance between the tectonic front and the shore of the islands, which ranges generally between $70-150 \mathrm{~km}$, has been reduced locally to $22 \mathrm{~km}$. Multichannel seismic data show that in this collision zone rocks of the arc slope return discontinuous, primarily trenchward-dipping reflections that contrast 


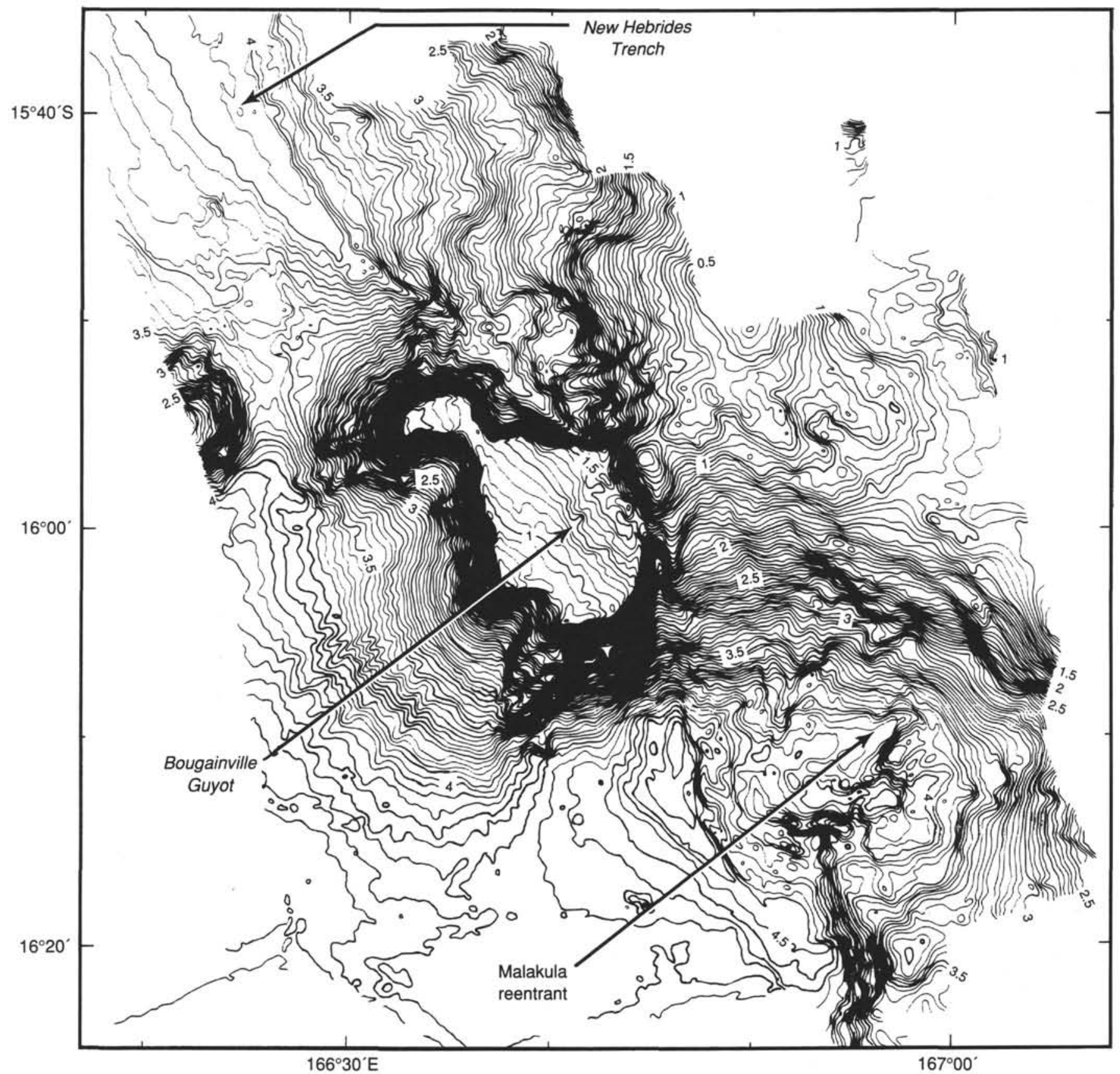

Figure 5. Seabeam bathymetric map of the collision zone between the Bougainville Guyot and the New Hebrides Island Arc. Bathymetry in kilometers; contour interval is $50 \mathrm{~m}$. The area covered is shown in Figure 1.

with arcward-dipping reflections that were imaged along the arc slope north and south of the collision zone (Fisher, 1986). The trenchward dip of the reflections in the collision zone suggests mass-wasting deposits that resulted from the uplift of the forearc islands.

Three-dimensional images of the morphology and structure of the arc slope obtained from Seabeam bathymetric and seismic reflection data emphasize major structural differences between the areas where the NDR and the Bougainville Guyot collide with the arc slope. In the next sections, we summarize the main structural characteristics of these two areas.

\section{The North d'Entrecasteaux Ridge-New Hebrides Island Arc Collision Zone}

In the NDR-New Hebrides Island Arc collision zone, Seabeam morphologic data show no indentation in the arc slope but a broad, shallow protrusion landward of the NDR. This protrusion extends 20 to $30 \mathrm{~km}$ horizontally and projects $1000-1500 \mathrm{~m}$ above the upper arc slope, culminating in the Wousi Bank (Fig. 3). Geophysical data collected across this collision zone also indicate that normal trench convergence has produced only a few trench-parallel structures confined to the toe of the arc slope, whereas the slightly oblique motion of 


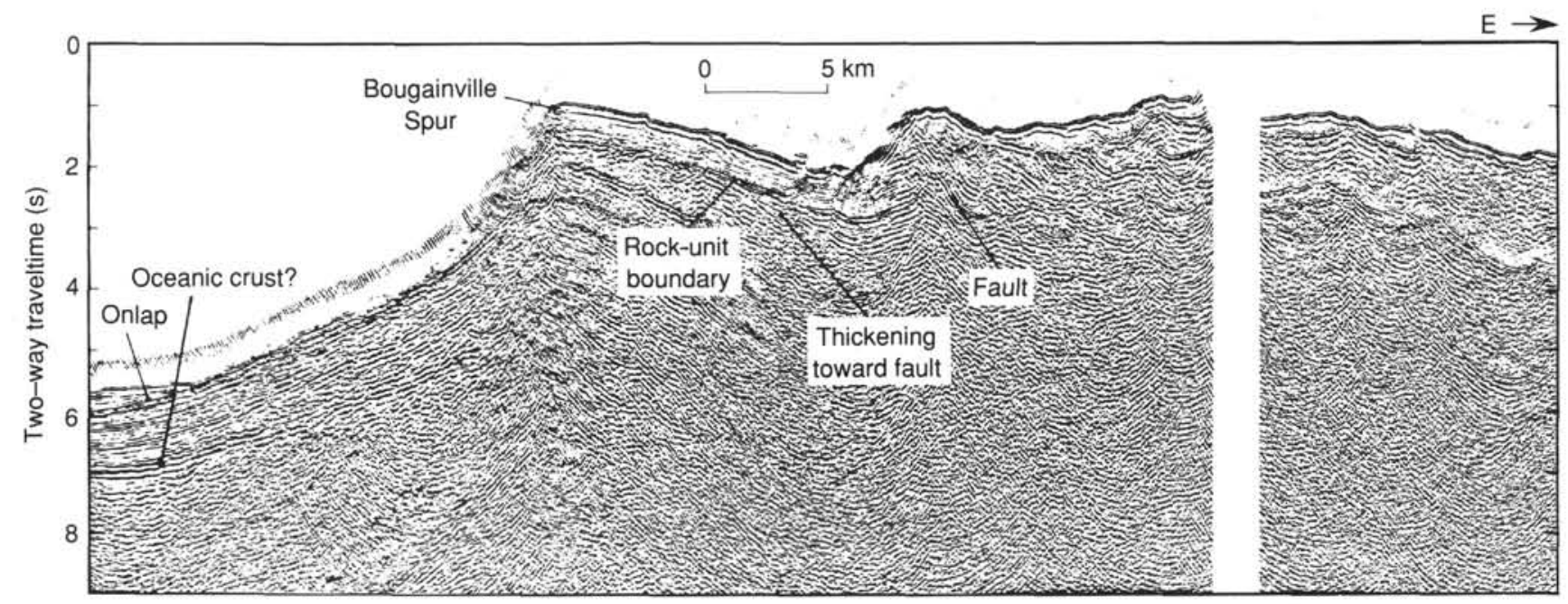

Figure 6. Migrated multichannel seismic reflection section (USGS line 100) across the Bougainville Guyot collision zone.

the NDR relative to the trench has resulted in well-developed structures that extend obliquely across the arc slope and form a strongly asymmetric three-dimensional tectonic pattern (Fig. 7; Collot and Fisher, 1991). North of the ridge the lower arc slope has a lobate structure formed by east-to-southeastdipping thrusts and lineaments trending $\mathrm{N} 60^{\circ} \mathrm{W}$ with apparent strike-slip displacement. The upper slope is shaped by slumps and a canyon network. The arc slope that lies directly over the subducted crest of the ridge forms the protrusion of the Wousi Bank bounded on its northern and southern sides by steep scarps. This protrusion has been uplifted, possibly by $1500-$ $2500 \mathrm{~m}$, causing northward block sliding along an extensional detachment surface. Immediately south of the ridge, the arc slope is the location of large slumps deformed by normal faults that trend parallel to the ridge axis.

Multichannel seismic reflection lines that cut through the arc slope in this collision zone do not show evidence for large faults or anticlines (Fisher et al., 1986). Rather, seismic profiles across the arc slope show evidence for slump deposits that are represented on the seismic sections by discrete bodies with divergent bedding dips. Apparently, slope rocks have such a low strength that mass-wasting deposits have formed in response to the collision instead of large relief structures (Fisher et al., 1991). Seismic section 104 (Fig. 4), which cuts through the arc slope along to the ridge axis, shows strong coherent reflections that extend from the ridge's top to beneath the arc slope. These reflections are interpreted as the décollement (Fisher et al., 1991). However, arc-slope rocks above the décollement are mainly nonreflective and do not show clear evidence for discrete thrust faults. This absence of clearly imaged thrust faults may indicate that arc-slope rocks were highly fractured by the collision.

As suggested by Seabeam data, multichannel seismic reflection data indicate that the arc-slope rocks deform in different ways north of the ridge and above the northern flank of the subducted ridge. North of the ridge, low-angle, east-tosoutheast-dipping thrust faults deform the toe of the arc slope whereas above the northern flank of the NDR, steep, southdipping reverse faults crosscut the arc slope and extend downward into the ridge flank. This extension suggests that the décollement lies locally within the ridge and that ridge material may be incorporated by tectonic accretion to the arc slope (Fisher et al., 1991). Drilling the toe of the arc slope above the ridge crest revealed accreted ridge material and the style of rock deformation.
Four dives conducted in the NDR arc collision zone (Fig. 2) revealed that volcanic and volcaniclastic rocks and sediments, probably derived from the island arc, make up most of the middle and upper arc slopes (Collot et al., 1989). The toe of the arc slope may locally include deep-water sediments that were accreted from the downgoing plate (Collot et al., unpubl. data). Along the upper arc slope, massive, fractured andesite and andesitic basalt underlie the Wousi Bank (dive 1 in Fig. 2) and probably represent the New Hebrides arc basement. These lavas are locally interbedded with volcaniclastic rocks. Above the subducted northern flank of the NDR, arc-slope rocks exposed at a seafloor scarp (dive 3 in Fig. 2) consist of north-dipping beds of upper Pliocene to Quaternary clayey volcanic siltstone, volcanic silty clay, and nannofossil foraminiferal mixed sedimentary rocks interbedded with volcanic breccias containing lower middle Miocene clasts of island-arc basalt (Fig. 8). Clasts of lower middle Miocene nannofossil and foraminiferal ooze were locally found displaced in uppermost Miocene clasts reworked in Pliocene to Quaternary sediments. The toe of the arc slope above the ridge's summit (dive 2 in Fig. 2) is blanketed with clay and the deformation front is marked by a west-facing scarp, 1-2 m high. North of the NDR (dive 4 in Fig. 2), the toe of the arc slope is highly fractured and sheared (Greene et al., this volume) and consists of a pile of upper Pleistocene calcareous volcanic siltstone with lower Pliocene to Quaternary calcareous mixed sedimentary rocks tectonically thrust between pale brown middle Oligocene to lower Miocene clayey nannofossil ooze and chalk. The siltstone and mixed sedimentary rocks are similar to those observed farther up along the arc slope and may include products derived from the nearby islands. The Oligocene to Miocene ooze and chalk that locally contain Eocene nannofossils drastically differ from the coarse volcaniclastic rocks of similar age exposed on Espiritu Santo Island but closely resemble the uppermost Eocene chalk and Oligocene nannofossil ooze cored at DSDP Site 286 on the downgoing plate (Shipboard Scientific Party, 1975). This close resemblance suggests that the Oligocene to Miocene ooze and chalk recovered at the toe of the arc slope were accreted from the Australia-India plate.

\section{The Bougainville Guyot-New Hebrides Island Arc Collision Zone}

In the Bougainville-New Hebrides collision zone, the Bougainville Guyot has clogged the trench and indented the 


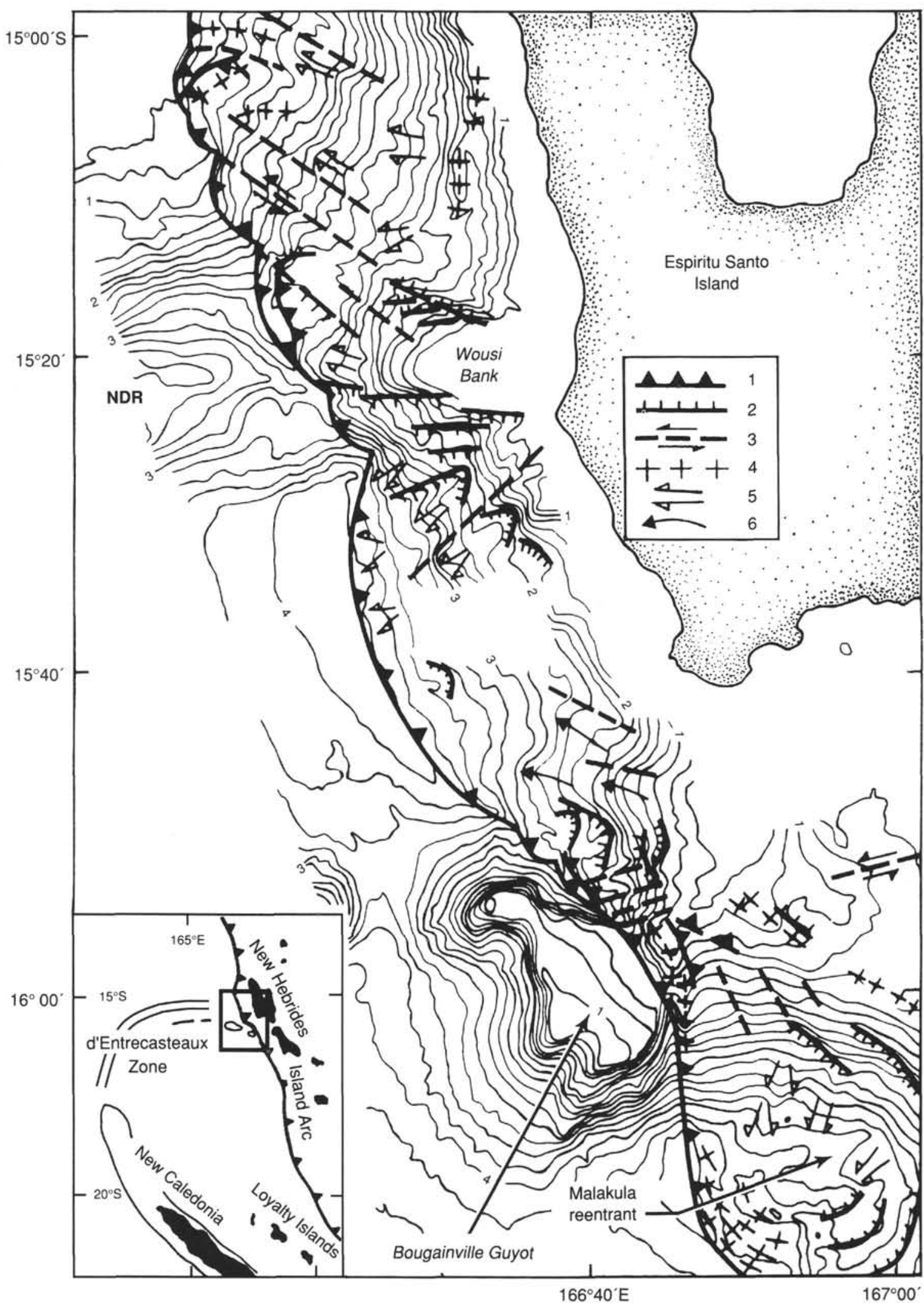

Figure 7. Structural interpretation of the collision zone between the d'Entrecasteaux Zone and the New Hebrides Island Arc based on Seabeam morphologic and seismic reflection data. Key to symbols: $1=$ trace of interplate décollement and thrust faults; $2=$ normal fault or scarp; $3=$ strike-slip faults; $4=$ axis of bathymetric high; $5=$ slumps; $6=$ direction of rock extrusion. NDR $=$ North d'Entrecasteaux Ridge. 


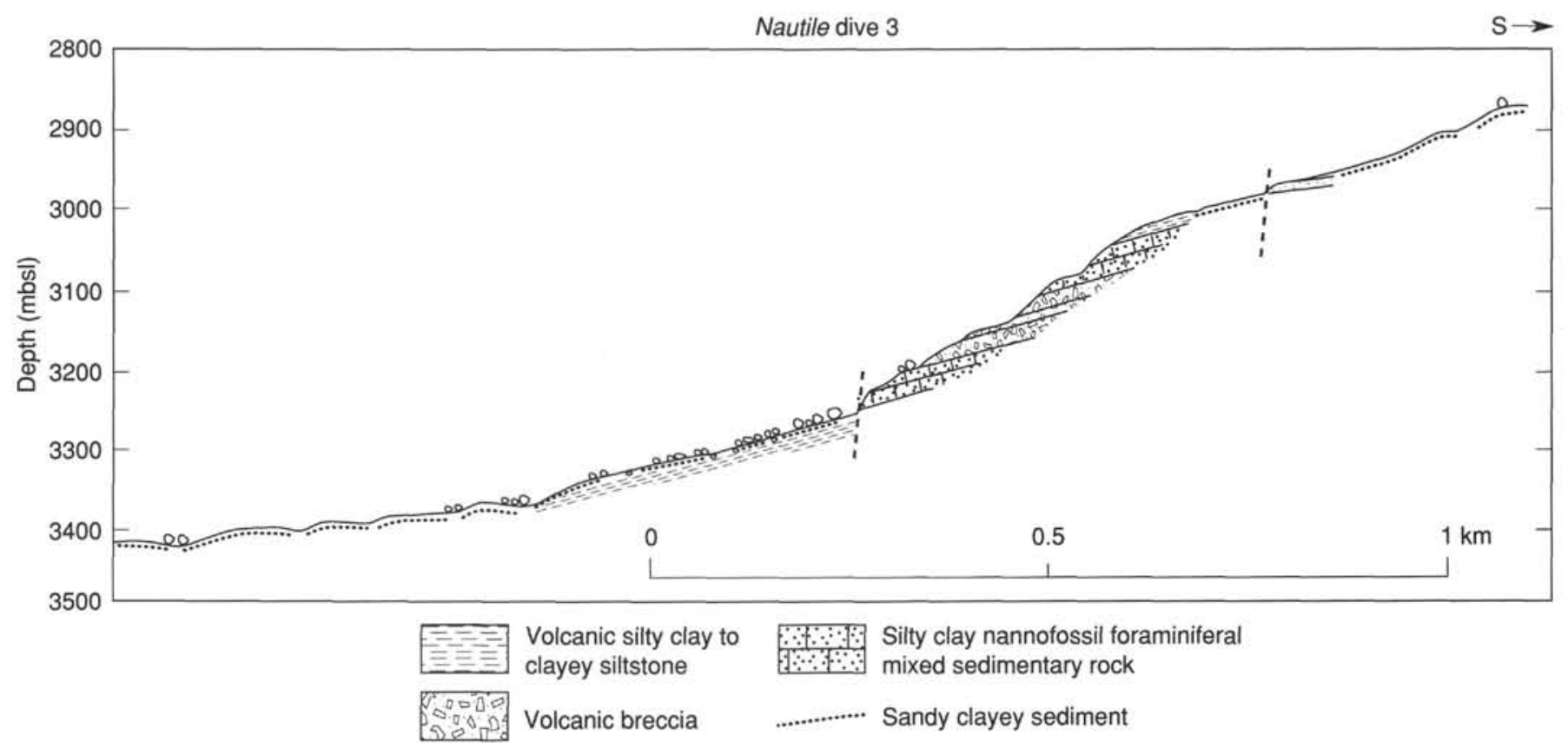

Figure 8. Geologic cross-section of a scarp of the New Hebrides Island Arc slope, north of the North d'Entrecasteaux Ridge. Section interpreted from the Nautile dive 3 (J.-P. Eissen, pers. comm., 1991). Depth is in meters below sea level (mbsl). No vertical exaggeration. Location is shown in Figure 2.

arc slope by $10 \mathrm{~km}$ to form a $5-\mathrm{km}$-wide, arcuate antiform in arc-slope rocks (Fig. 5). This antiform towers above the guyot platform by about $800 \mathrm{~m}$. The plate contact zone is marked by a 300 -m-wide depression that extends along the steep western slope of the antiform and is connected to the trench northward and southward by deep canyons. Material dislodged from the arc slope as a result of the collision travels along these canyons to the trench.

Seabeam morphologic data indicate that southeast of the Bougainville Guyot the Malakula reentrant (Fig. 5) forms a deep embayment into the arc slope. This reentrant may be a scar of a past collision between the forearc and a nowsubducted seamount (Collot and Fisher, 1989). The scar is believed to be healing by the growth of a fold-and-thrust belt that develops across the mouth of the reentrant and traps material slumped from its walls (Fig. 7).

Contrasting morphologic patterns observed along the arc slope in the Bougainville collision zone suggest that arc-slope rocks north of the Bougainville Guyot offer more resistance to lateral deformation than do the arc-slope rocks southeast of the guyot where the Malakula reentrant indents the arc slope. North of the impact zone, bulges of rocks trending oblique to the arc slope suggest that arc-slope rocks are compressed and extruded trenchward following the arrows shown in Figure 7. Between the bulges and the guyot, the arc slope is deformed by steep arcuate scarps that suggest slump scars; a series of lineaments $\mathrm{N} 75^{\circ} \mathrm{E}$ also cross-cut the arc slope, suggesting severe fracturing and collapse of arc-slope rocks. South of the impact zone of the guyot, Seabeam morphology of the southfacing arc slope is relatively regular. At this location arc-slope rocks pushed by the collision appear to slide along the slope toward the Malakula reentrant and hence contribute to smoothing the walls of the reentrant.

Multichannel seismic reflection data show that the arc slope in the Bougainville collision zone has been considerably shortened in the east-west direction and that the arc slope comprises a collision complex that may involve pieces of the guyot (Fisher et al., in press). Multichannel seismic line 100, which cuts through the guyot and its collision zone, shows that the base of the guyot's carbonate cap extends for about 1 $\mathrm{km}$ eastward beneath the antiform to where the base ends abruptly (Fig. 6). The eastern part of seismic line 100 show sets of strong, parallel, east-dipping reflections that differ from reflections generally returned by arc-slope rocks that lie away from the collision zone. The strong reflections may be from blocks of guyot rocks (Fisher et al., in press). The spatial distribution of these tilted reflections suggests that they are separated by east-dipping thrust faults. One possibility is that either cap rocks or apron sediments of the guyot have been detached and imbricated to form a collision complex as the arc rode up the east flank of the guyot. Drilling in this collision zone will show whether these steeply dipping rocks originated from the guyot or from the arc.

Observations and samples collected during three dives of the Nautile (Fig. 2) near the toe of the arc slope in the Bougainville collision zone reveal a $500-\mathrm{m}$-thick wedge of highly deformed and imbricated rocks overlain by less-deformed island-arc rocks and sediments (Collot et al., unpubl. data). The wedge that was observed during dive 5 (Fig. 9) includes minor siltstone and sandstone and major thrusts of upper Oligocene to lower Miocene reefal limestones that rework upper Eocene reefal debris and middle Eocene pelagic sediments. These imbricated rocks were possibly accreted from the Bougainville Guyot or from an already subducted seamount. Arc-slope rocks overlying the wedge consist of upper Pliocene to Quaternary interbedded calcareous volcanic siltstone and sandstone gently tilted arcward. Similar rocks with volcanic breccias and conglomerate were observed during dive 7 (Fig. 2). At the location of dive 6 (Fig. 2) the accreted wedge is not exposed at the seafloor; rather, volcanic siltstone and sandstone interbedded with whitish volcaniclastic debris flows form most of the outcrops. These rocks are tilted arcward by $30^{\circ}-60^{\circ}$ but do not show evidence for tectonic deformation by compression. Instead they show slumps and synsedimentary folds warped to the southwest, suggesting that sediment was deposited on a southwest- 


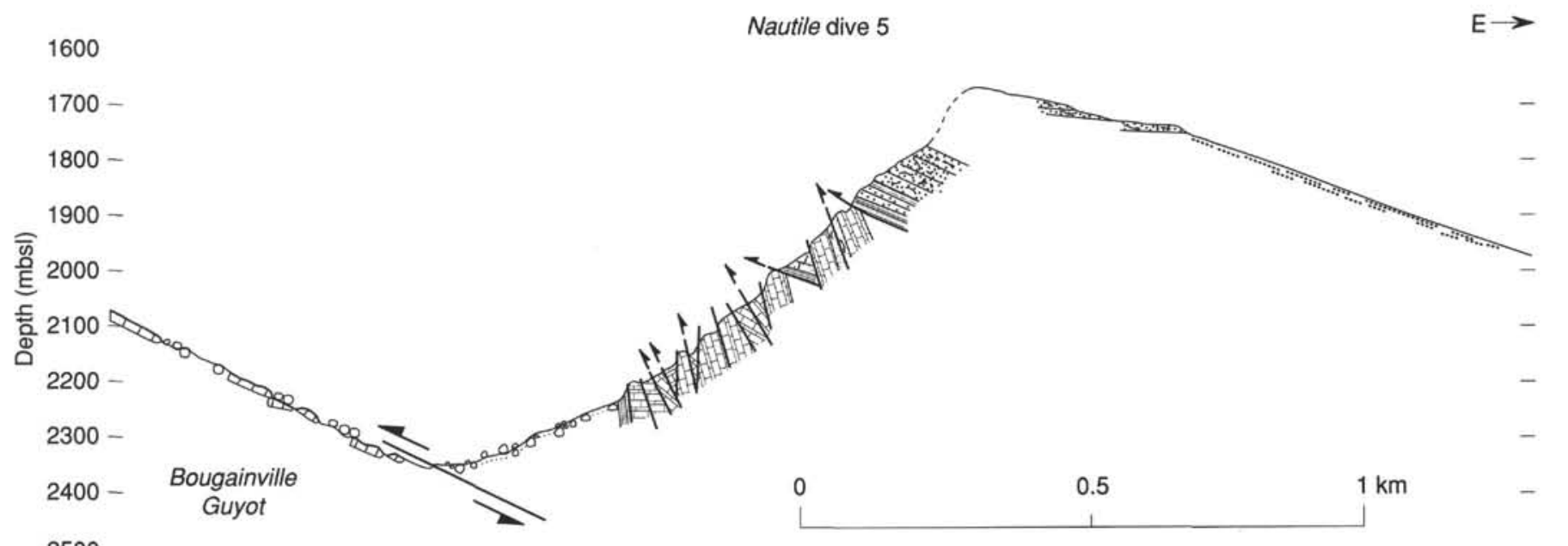

2500
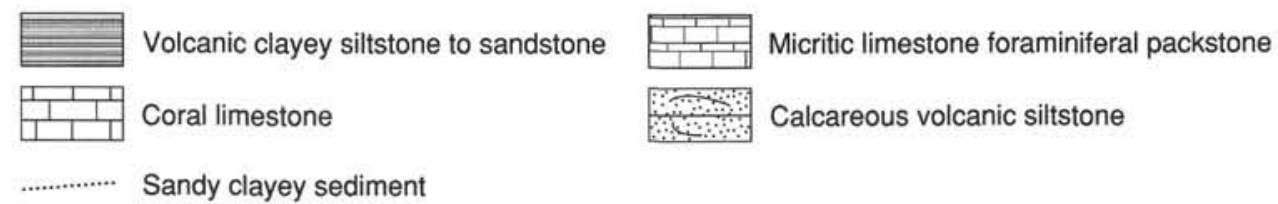

Figure 9. Geologic cross-section of the toe of the New Hebrides Island Arc slope southeast of the Bougainville Guyot's flank. Section interpreted from the Nautile dive 5 (S. Lallemand, pers. comm., 1991). Depth is in meters below sea level (mbsl). No vertical exaggeration. Location is shown in Figure 2.

dipping paleosurface which was recently tilted arcward (Collot et al., 1989). A few samples collected during dive 6 , in a scree at the base of the western flank of the antiform, differ in lithology and age from the rest of the arc slope explored during this dive. These samples consist of highly tectonized Miocene to Pliocene pelagic limestone and upper Oligocene to lower Miocene chalk and limestone similar to those recovered from the accreted wedge at dive 5 . Therefore, lithologic and structural data suggest that a wedge of accreted rocks forms the heart of the disrupted antiform and that this wedge is overlain by less-deformed island-arc rocks that were uplifted and tilted arcward during the collision.

\section{DISCUSSION AND CONCLUSIONS}

Most of the morphologic and structural differences between the NDR and the Bougainville Guyot collision zones can be accounted for by differences in the morphology and stage of collision of the two colliding features. However, an understanding of physical properties of rocks in the collision zones as well as the role of the fluids can be critical to the interpretation of these differences. Geophysical data indicate that less than a third of the body of the Bougainville Guyot is buried in the subduction zone, suggesting that the guyot is still in the initial stage of collision defined by Lallemand and Le Pichon (1987). During the initial stage of the collision, the accretionary wedge thickens tectonically by thrust faulting, and in map view the arc slope is deeply indented by the seamount. These features, including a high-standing antiform, are recognized landward of the Bougainville Guyot and appear to be well developed because the guyot allows the compressive stresses to be concentrated on a relatively small impact surface. The NDR extends as a continuous, gently eastwarddipping body for at least $15 \mathrm{~km}$ beneath the arc slope. No indentation is evident landward of the NDR and geophysical data show neither antiform nor clear evidence for east-dipping thrust faults, suggesting that the ridge has already passed the early stage of the collision described by Lallemand and Le Pichon (1987). In contrast with arc-slope structures landward of the guyot, the arc slope in the NDR collision zone is characterized by a broad, strongly uplifted area (the Wousi Bank) that is larger and shallower than the uplifted area landward of the Bougainville Guyot. Moreover, east of the NDR the arc-slope structure is dominantly characterized by normal faults and strike-slip lineaments transverse to the arc slope. Therefore, the Bougainville Guyot appears to impinge upon the arc slope, creating considerable shortening in the forearc, whereas the linear NDR is more continuous beneath the arc slope and has mainly uplifted arc-slope rocks as well as the island-arc basement. Although the collision affects progressively more northward parts of the arc slope because of the northward creeping of the DEZ along the trench, the NDR appears to be subducting in a relatively more steady-state regime than does the Bougainville Guyot.

The two collision zones also show similarities. Both collision zones are characterized by strong tectonic erosion and large mass wasting. Block sliding and slumping of rocks of oversteepened parts of the arc slope are found in both collision zones. Slump deposits locally make up most of the arc-slope rocks north and south of the Wousi Bank. Such deposits, although less thick, also cover the arc slope landward of the guyot. Collapse of arc-slope rocks, which occurs when the arc-slope rocks lose support as the oceanic feature is subducted, results in tectonic erosion and mass wasting. This is the case in the wake of the NDR where the arc slope is deformed by transverse normal faults and large slumps. Rock disruption and mass wasting extend for about $20 \mathrm{~km}$ in the wake of the ridge. This is also the case immediately south of the Bougainville Guyot where the Malakula reentrant indents the arc slope. The stepped morphology of parts of the wall encircling the reentrant together with the hummocky topography of its bottom (Fig. 7) suggest that the arc slope collapsed. This collapse could be due to the past subduction of a seamount.

Geologic data presented in this report indicate that the shallow lithology of the arc slope landward of the DEZ is relatively homogeneous and consists mainly of Pliocene to 
Quaternary volcaniclastic rocks and sediments probably derived from nearby Espiritu Santo Island. These rocks contain clasts of lower middle and uppermost Miocene, but upper middle to lower upper Miocene rocks were never recovered during the dives, suggesting a gap that can be related to the 11to 8-Ma emergent phase recognized on the Western Belt of the New Hebrides Island Arc (Carney et al., 1985).

Variations in lithology do exist along the arc slope and may correlate with major structural differences between the two collision zones. These variations can be illustrated by two examples. Volcanic island-arc basement is exposed along a large normal fault in the southern flank of the Wousi Bank because this bank was uplifted above the NDR and progressively collapsed in the wake of the ridge. However, volcanic island-arc basement was not recognized in the Bougainville collision zone, which apparently suffers less collapse but more compressional deformation than does the arc slope east of the NDR. However, a peridotite fragment recovered in a scree landward of the Bougainville collision zone (Collot et al., unpubl. data) suggests that deep crust or mantle may outcrop in this area. This peridotite, unknown on the nearby islands, may indicate that the collision of the guyot has a profound influence on the forearc structure. However, the peridotite could be equally derived from the deep crust or mantle of the DEZ.

The other example of lithologic variation along the arc slope is provided by rocks interpreted as accreted at the toe of the arc slope. Deep-water Oligocene sediments containing reworked Eocene nannofossils exposed at the toe of the arc slope north of the NDR may have been scraped off the downgoing oceanic crust, the lower flank of the NDR, or the West Torres Plateau (Fig. 1). In contrast, shallow-water reefal packstones of late Oligocene to early Miocene age, which may originate from the Bougainville Guyot or from a previous subducted seamount, are exposed at the toe of the arc landward of the guyot.

Collisions of a ridge and a guyot with the New Hebrides Island Arc slope have produced specific morphologic and structural imprints in arc-slope rocks. However, although both types of collision may have resulted in local tectonic accretion, tectonic erosion and mass wasting appear to be the most important factors that shape the island-arc slope in a collision zone.

\section{REFERENCES}

Auzende, J. M., Lafoy, Y., and Marsset, B., 1988. Recent geodynamic evolution of the north Fiji Basin (southwest Pacific). Geology, 16:925-929.

Ballance, P. F., Scholl, D. W., Vallier, T. L., Stevenson, A. J., Ryan, H., Quinterno, P., Blome, C., Barron, J. A., Bukry, D., Cawood, P. A., Chaproniere, G.C.H., Herzer, R. H., and Tappin, D. R., 1989. Subduction of a Late Cretaceous seamount of the Louisville ridge at the Tonga trench-accretion, arc fragmentation and accelerated subduction erosion. Tectonics, 8:953-962.

Burne, R. V., Collot, J.-Y., and Daniel, J., 1988. Superficial structures and stress regimes of the downgoing plate associated with subduction-collision in the Central New Hebrides Arc (Vanuatu). In Greene, H. G., and Wong, F. L. (Eds.), Geology and Offshore Resources of Pacific Island Arcs-Vanuatu Region. Circum-Pac. Council Energy Miner. Resour., Earth Sci. Ser., 8:357-376.

Carney, J. N., and Macfarlane, A., 1982. Geological evidence bearing on the Miocene to Recent structural evolution of the New Hebrides arc. Tectonophysics, 87:147-175.

Carney, J. N., Macfarlane, A., and Mallick, D.I.J., 1985. The Vanuatu island arc-an outline of the stratigraphy, structure, and petrology. In Nairn, A.E.M., Stehli, F. G., and Uyeda, S. (Eds.), The Ocean Basins and Margins (Vol. 7): New York (Plenum), 685-718.
Chase, C. G., 1971. Tectonic history of the Fiji plateau. Geol. Soc. Am. Bull., 82:3087-3110.

Collot, J.-Y., Daniel, J., and Burne, R. V., 1985. Recent tectonics associated with the subduction/collision of the D'Entrecasteaux zone in the central New Hebrides. Tectonophysics, 112:325-356.

Collot, J.-Y., and Fisher, M. A., 1988. Crustal structure, from gravity data, of a collision zone in the central New Hebrides Island Arc. In Greene, H. G., and Wong, F. L. (Eds.), Geology and Offshore Resources of Pacific Island Arcs-Vanuatu Region. Circum-Pac. Counc. Energy and Miner. Resour., Earth Sci. Ser., 8:125-140.

1989. Formation of forearc basins by collision between seamounts and accretionary wedges: an example from the New Hebrides subduction zone. Geology, 17:930-933.

1991. The collision zone between the North d'Entrecasteaux Ridge and the New Hebrides Island Arc. Part 1: Seabeam morphology and shallow structure. J. Geophys. Res., 96:44574478.

Collot, J.-Y., Pelletier, B., Boulin, J., Daniel, J., Eissen, J.-P., Fisher, M. A., Greene, H. G., Lallemand, S., and Monzier, M., 1989. Premiers résultats des plongées de la campagne SUBPSO1 dans la zone de collision des rides d'Entrecasteaux et de l'arc des Nouvelles-Hébrides. C. R. Acad. Sci. Ser. 2, 309:1947-1954.

Daniel, J., Collot, J. Y., Monzier, M., Pelletier, B., Butscher, J., Deplus, C., Dubois, J., Gérard, M., Maillet, P., Monjaret, M. C., Récy, J., Renard, V., Rigolot, P., and Temakon, S. J., 1986. Subduction et collision le long de l'arc des Nouvelles-Hébrides (Vanuatu): résultats préliminaires de la campagne SEAPSO (Leg 1). C. R. Acad. Sci. Ser. 2, 303:805-810.

Daniel, J., Jouannic, C., Larue, B., and Récy, J., 1977. Interpretation of d'Entrecasteaux zone (north of New Caledonia). Int. Symp. on Geodynamics in South-west Pacific, Noumea, New Caledonia, 1976. Paris (Editions Technip), 117-124.

Dubois, J., Deplus, C., Diament, M., Daniel, J., and Collot, J.-Y., 1988. Subduction of the Bougainville seamount (Vanuatu): mechanical and geodynamic implications. Tectonophysics, 149:111119.

Fisher, M. A., 1986. Tectonic processes at the collision of the D'Entrecasteaux zone and the New Hebrides island arc. J. Geophys. Res., 91:10470-10486.

Fisher, M. A., Collot, J.-Y., and Geist, E. L., 1991. The collision zone between the North d'Entrecasteaux Ridge and the New Hebrides Island Arc. Part 2: structure from multichannel seismic data. $J$. Geophys. Res., 96:4479-4495.

in press. Structure of the collision zone between Bougainville Guyot and the accretionary wedge of the New Hebrides Island Arc, Southwest Pacific. Tectonics.

Fisher, M. A., Collot, J.-Y., and Smith, G. L., 1986. Possible causes for structural variation where the New Hebrides island arc and the d'Entrecasteaux zone collide. Geology, 14:951-954.

Fryer, P., and Smoot, N. C., 1985. Processes of seamount subduction in the Mariana and Izu-Bonin trenches. Mar. Geol., 64:77-90.

Isacks, B. L., Cardwell, R. K., Chatelain, J. L., Barazangi, M., Marthelot, J.-M., Chinn, D., and Louat, R., 1981. Seismicity and tectonics of the central New Hebrides island arc. In Simpson, D. W., and Richards, P. G. (Eds)., Earthquake Prediction: An International Review. Am. Geophys. Union, Maurice Ewing Ser., 4:93-116.

Jouannic, C., Taylor, F. W., Bloom, A. L., and Bernat, M., 1980. Late Quaternary uplift history from emerged reef terraces on Santo and Malekula Islands, central New Hebrides island arc. Tech. Bull.-U. N. Econ. Soc. Comm. Asia Pac., CCOPISOPAC, 3:91-108.

Kobayashi, K., Cadet, J., Aubouin, J., Boulègue, J., Dubois, J., von Huene, R., Jolivet, L., Kanazawa, T., Kasahara, J., Koisumi, K., Lallemand, S., Nakamura, Y. P., Suyehiro, K., Tani, S., Tokuyama, H., and Yamazaki, T., 1987. Normal faulting of the Daiichi-kashima seamount in the Japan trench revealed by the Kaiko I cruise, Leg 3. Earth Planet. Sci. Lett., 83:257-266.

Lallemand, S., and Le Pichon, X., 1987. Coulomb wedge model applied to the subduction of seamounts in the Japan trench. Geology, 15:1065-1069.

Louat, R., and Pelletier, B., 1989. Seismotectonics and present-day relative plate motions in the New Hebrides-North Fiji basin region. Tectonophysics, 167:41-55. 
Luyendyk, B. P., Bryan, W. B., and Jezek, P. A., 1974. Shallow structure of the New Hebrides island arc. Geol. Soc. Am. Bull., 85:1287-1300.

Macfarlane, A., Carney, J. N., Crawford, A. J., and Greene, H. G., 1988. Vanuatu-a review of the onshore geology. In Greene, H. G., and Wong, F. L. (Eds.), Geology and Offshore Resources of Pacific Island Arcs-Vanuatu Region. Circum-Pac. Counc. Energy and Miner. Resour., Earth Sci. Ser., 8:45-92.

Maillet, P. M., Monzier, M., Selo, M., and Storzer, D., 1983. The d'Entrecasteaux zone (southwest Pacific): a petrological and geochronological reappraisal. Mar. Geol., 53:179-197.

Mallick, D.I.J., 1973. Some petrological and structural variations in the New Hebrides. In Coleman, P. J. (Ed.), The Western Pacific: Island Arcs, Marginal Seas, Geochemistry: Perth (Univ. of Western Australia Press), 193-211.

Mallick, D.I.J., and Greenbaum, D., 1977. Geology of Southern Santo. Reg. Rep.-New Hebrides Geol. Surv., 1-84.

Minster, J. B., and Jordan, T. H., 1978. Present-day plate motions: $J$. Geophys. Res., 83:5331-5354.

Mitchell, A.H.G., and Warden, A. J., 1971. Geological evolution of the New Hebrides island arc. J. Geol. Soc. London, 127:501-502.

Montaggioni, L., Butterlin J., Glaçon, G., Collot, J.-Y., Monzier, M., Pelletier, B., Boulin, J., Lallemand, S., Daniel, J., Faure, G. Lauriat-Rage, A., Vénec-Peyré, M. T., Blondeau, A., Lozouet, P., Vacelet, J., and Babinot, J. F., in press. Résultats des plongées SUBPSO1 du Nautile: signification géodynamique des calcaires de plate-forme le long de la zone de subduction des NouvellesHébrides (Sud-Ouest Pacifique). C. R. Acad. Sci. Ser. 2.
Pelletier, B., and Dupont, J., 1990. Effets de la subduction de la ride de Louisville sur l'arc des Tonga-Kermadec. Oceanol. Acta, 10:57-76.

Pontoise, B., and Tiffin, D., 1986. Seismic refraction results over the d'Entrecasteaux zone west of the New Hebrides arc. Geodynamique, 2:109-120.

Shipboard Scientific Party, 1975. Site 286. In Andrews, J. E., Packham, G., et al., Init. Repts. DSDP, 30: Washington (U.S. Govt. Printing Office), 69-131.

Taylor, F. W., Frohlich, C., Lecolle, J., and Strecker, M. R., 1987. Analysis of partially emerged corals and reef terraces in the central Vanuatu arc: comparison of contemporary coseismic and nonseismic with Quaternary vertical movements. J. Geophys. Res., 92:4905-4933.

Taylor, F. W., Isacks, B. L., Jouannic, C., Bloom, A. L., and Dubois, J., 1980. Coseismic and Quaternary vertical tectonic movements, Santo and Malekula Islands, New Hebrides island arc. J. Geophys. Res., 85:5367-5381.

von Huene, R., and Lallemand, S., 1990. Tectonic erosion along the Japan and Peru convergent margins. Geol. Soc. Am. Bull., 102:704-720.

Weissel, J. K., Watts, A. B., and Lapouille, A., 1982. Evidence for late Paleocene to late Eocene sea floor in the southern New Hebrides Basin. Tectonophysics, 87:243-251.

Ms 134A-102 